\title{
On the Anatolian Origins of Some Late Bronze Egyptian Vessel Forms
}

\section{Hélène Bouillon}

\section{Q OpenEdition \\ 1 Journals}

\section{Electronic version}

URL: http://journals.openedition.org/anatoliaantiqua/342

DOI: 10.4000/anatoliaantiqua.342

\section{Publisher}

IFEA

\section{Printed version}

Date of publication: 1 June 2015

Number of pages: 1-10

ISBN: 9782362450600

ISSN: 1018-1946

\section{Electronic reference}

Hélène Bouillon, « On the Anatolian Origins of Some Late Bronze Egyptian Vessel Forms », Anatolia

Antiqua [Online], XXIII | 2015, Online since 30 June 2018, connection on 18 December 2020. URL : http://journals.openedition.org/anatoliaantiqua/342 ; DOI : https://doi.org/10.4000/anatoliaantiqua. 342 


\title{
ANATOLIA ANTIQUA ESKI ANADOLU
}

\author{
XXIII
}

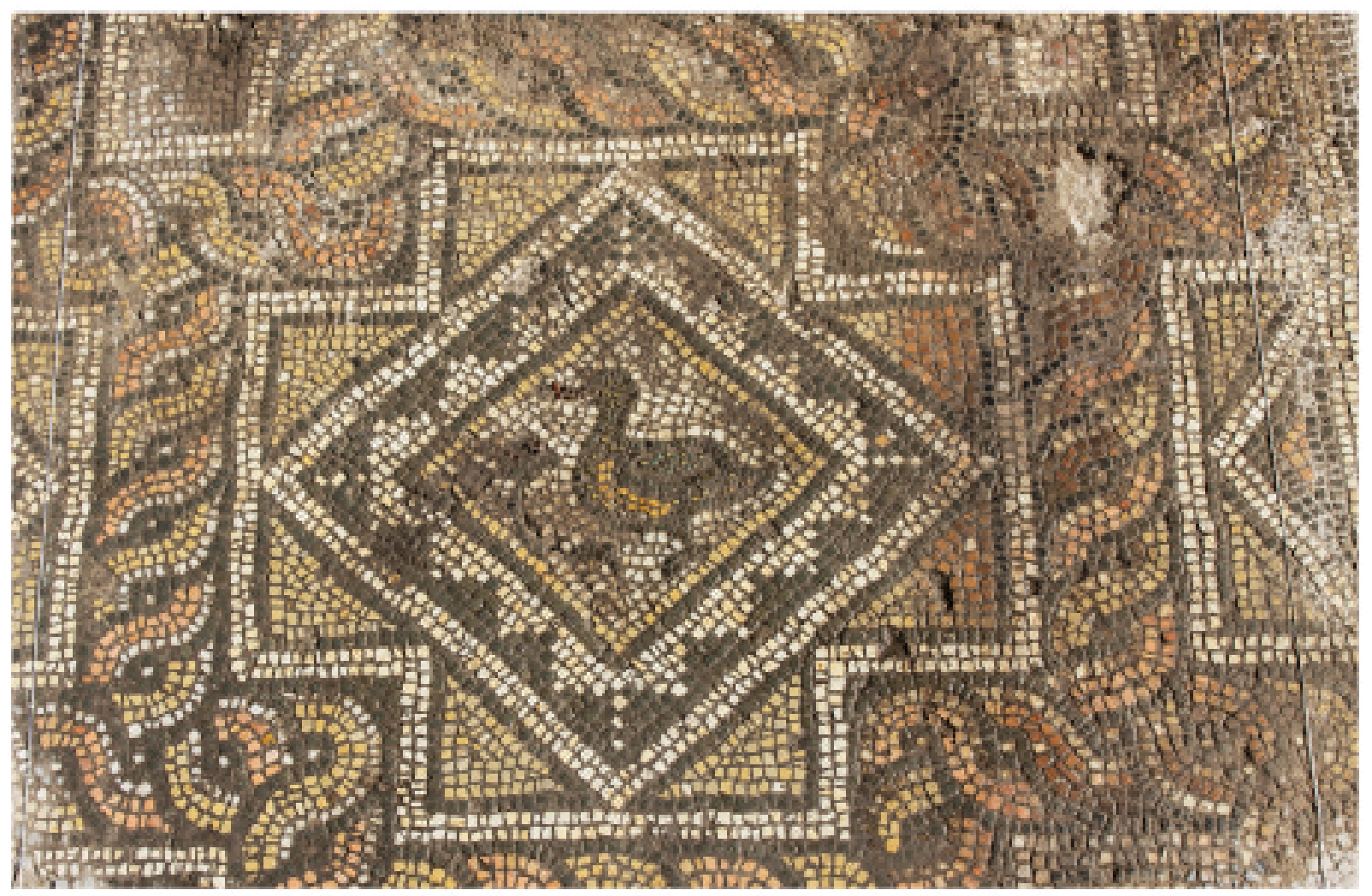

INSTITUT FRANC̣AIS D'ETUDES ANATOLIENNES GEORGES-DUMEZIL CNRS USR 3131 


\section{TABLE DES MATIERES}

Hélène BOUILLON,

On the anatolian origins of some Late Bronze egyptian vessel forms

Agneta FRECCERO,

Marble trade in Antiquity. Looking at Labraunda

Şehnaz ERASLAN,

Dionysus and Ariadne in the light of Antiocheia and Zeugma Mosaics

Ergün LAFLI et Gülseren KAN ŞAHIN,

Middle Byzantine ceramics from Southwestern Paphlagonia

Mustafa AKASLAN, Doğan DEMIRCİ et Özgür PERÇİN en collaboration avec Guy LABARRE, L'église paléochrétienne de Bindeos (Pisidie)

Anaïs LAMESA,

La chapelle des Donateurs à Soğanlı, nouvelle fondation de la famille des Sképidès

Martine ASSENAT et Antoine PEREZ,

Localisation et chronologie des moulins hydrauliques d'Amida. A propos d'Ammien Marcellin,

XVIII, 8,11

Helke KAMMERER-GROTHAUS,

$»$ Ubi Troia fuit«

Atzik-Köy - Eine Theorie von Heinrich Nikolaus Ulrichs (1843)

CHRONIQUES DES TRAVAUX ARCHEOLOGIQUES EN TURQUIE, 2015

Sami PATACI et Ergün LAFLI,

Surveys in Ardahan on the turkish-georgian borderline in 2013 and 2014

Çĭ̆dem MANER,

Preliminary report on the second season of the Konya-Ereğli survey (KEYAR) 2014

Dominique BEYER, Can KARAVUL, Françoise LAROCHE-TRAUNECKER et Aksel TiBBET,

Rapport préliminaire sur les travaux de la mission archéologique de Zeyve Höyük-Porsuk 2014

Jean-Charles MORETTI avec la collaboration de Nicolas BRESCH, Isabel BONORA,

Jean-Jacques MALMARY et Olivier RISS,

Claros, le temple d'Apollon : travaux réalisés en 2014

Olivier HENRY et Erika ANDERSSON, Christophe BOST, Ömür Dünya ÇAKMAKLI, Angela COMMITO, Mélissa CORMIER-HUGUET, Peter DE STAEBLER, Pierre DUPONT, Duygu ERGENÇ, Axel FREJMAN, Banu KEPENEK, Pascal LEBOUTEILLER, Haral NILSSON, Felipe ROJAS, Baptiste VERGNAUD, 


\section{Hélène BOUILLON*}

\section{ON THE ANATOLIAN ORIGINS OF SOME LATE BRONZE EGYPTIAN VESSEL FORMS}

New Kingdom Egypt has long been thought to be an Empire, whose political power extended over Nubia and a great part of the Levant ${ }^{2}$. While the expression 'Egyptian influence' is in fact quite vague, and fails to describe a well-defined phenomenon ${ }^{3}$, Egypt's cultural impact on the Near East remains a topic that is commonly used to explain many iconographies and artistic forms ${ }^{4}$. One of the most characteristic subjects of this supposed Egyptian prestige is luxury vessels ${ }^{5}$. Current research, however, has tended to reappraise Egypt's influence. Late Bronze Age artefacts are now being placed in a broader spectrum of investigation about contacts, exchange and international trade and diplomacy ${ }^{6}$.

The Egyptian tradition of vessel-making is very ancient. During the Badarian period (late $5^{\text {th }}$ - early $4^{\text {th }}$ millennium B.C. $)^{7}$ the first appearance of luxury vases is linked to the beginning of a social hierarchy visible in cemeteries ${ }^{8}$. The most important tombs contain the first Egyptian stone vases, but also the first zoomorphic ivory vases ${ }^{9}$. The first use of metal in the manufacture of vessels took place during $\mathrm{Na}-$ gada II (3500-3200 B.C.): gold and silver leaf adorns the lip or handles of the vases ${ }^{10}$. Tombs and cultic contexts of the following Dynasty I (3000-2890 B.C.) introduced small vessels in faience ${ }^{11}$. The major innovation of the Old Kingdom (2686-2160 B.C.) was the development of metalwork. It allowed the production of powerful tools for drilling and shaping stone vases, and soon, artisans also created vases entirely in metal. Thus appeared the first imitations of metal vases in other materials, including ceramics of high quality, commonly known as $\mathrm{Mei}$ dum ware $^{12}$. This phenomenon of imitation, already observed in earlier times between ceramic forms and stone vessels, is one of the keys to the typological study of luxury tableware in Ancient Egypt. Metal and stone were the two materials of choice for luxury vessels. Unfortunately, the recyclability of the former usually prevented its preservation. Thus the typological study of luxury vases necessarily relies on stone vases forms.

The evolution of Egyptian vessel forms from Neolithic times onwards has been studied since the end of the XIX ${ }^{\text {th }}$ century, essentially as a clue for dating $^{13}$. During the New Kingdom (1550-1069 B.C.), corresponding to the Late Bronze Age, many new forms and techniques appeared in Egypt (Fig. 1), most of them during the reigns of Hatchepsut (1473$1458)$ and Tuthmosis III (1479-1425). We can recognize the same forms on wall-paintings and reliefs in tombs and temples, among the gifts presented to

*) Conservateur du patrimoine < bouillon.helene@gmail.com>

1) This article summarizes one part of my doctoral research, and was carried out in Turkey during the summer of 2014, with a scholarship from the IFEA. My acknowledgments go to Jean-François Pérouse, director of the IFEA, and to Olivier Henry and Aksel Tibet for their advice and assistance with contacts during my stay. I also thank-Eric Jean, Ekin Kozal and Aslı Özyar for their kind help during the summer, and Marie-Henriette Gates for proofreading and corrections.

2) Aldred 1979; Redford 1993; Warburton 2001.

3) Shaw 2000: 224 (map).

4) Freed 1982; Jacobsson 1994; Phillips 2008.

5) Caubet 1991; Bevan 2007; Sparks 2007.

6) Lilyquist 1997; Feldman 2005; Aruz 2009; Lilyquist 2012; Aruz 2013

7) See the Oxford chronology in Shaw 2000.

8) Midant-Reynes 2003.

9) British Museum AE 63057 (Harrell 2012: fig. 22).

10) Cf. Louvre Museum E 23206 and E 23238.

11) Vandier 1952: t.2, fig. 523.

12 Produced between 2650 and 2250 B.C., approximately (Kammerer-Grothaus 1998).

13) Bissing 1907; Reisner 1931: 130-177; Petrie 1937; El-Khouli 1978; Aston 1994. 


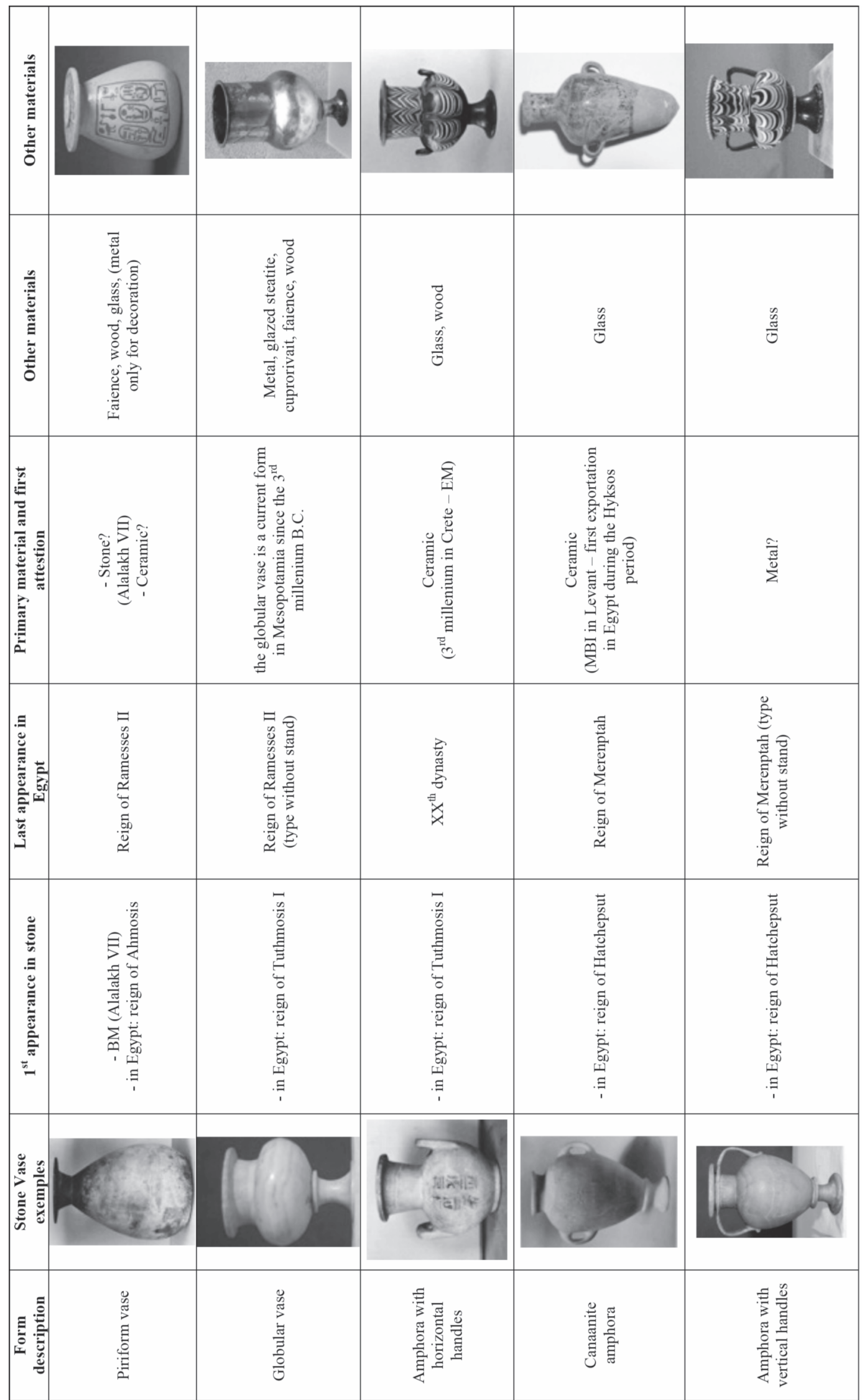




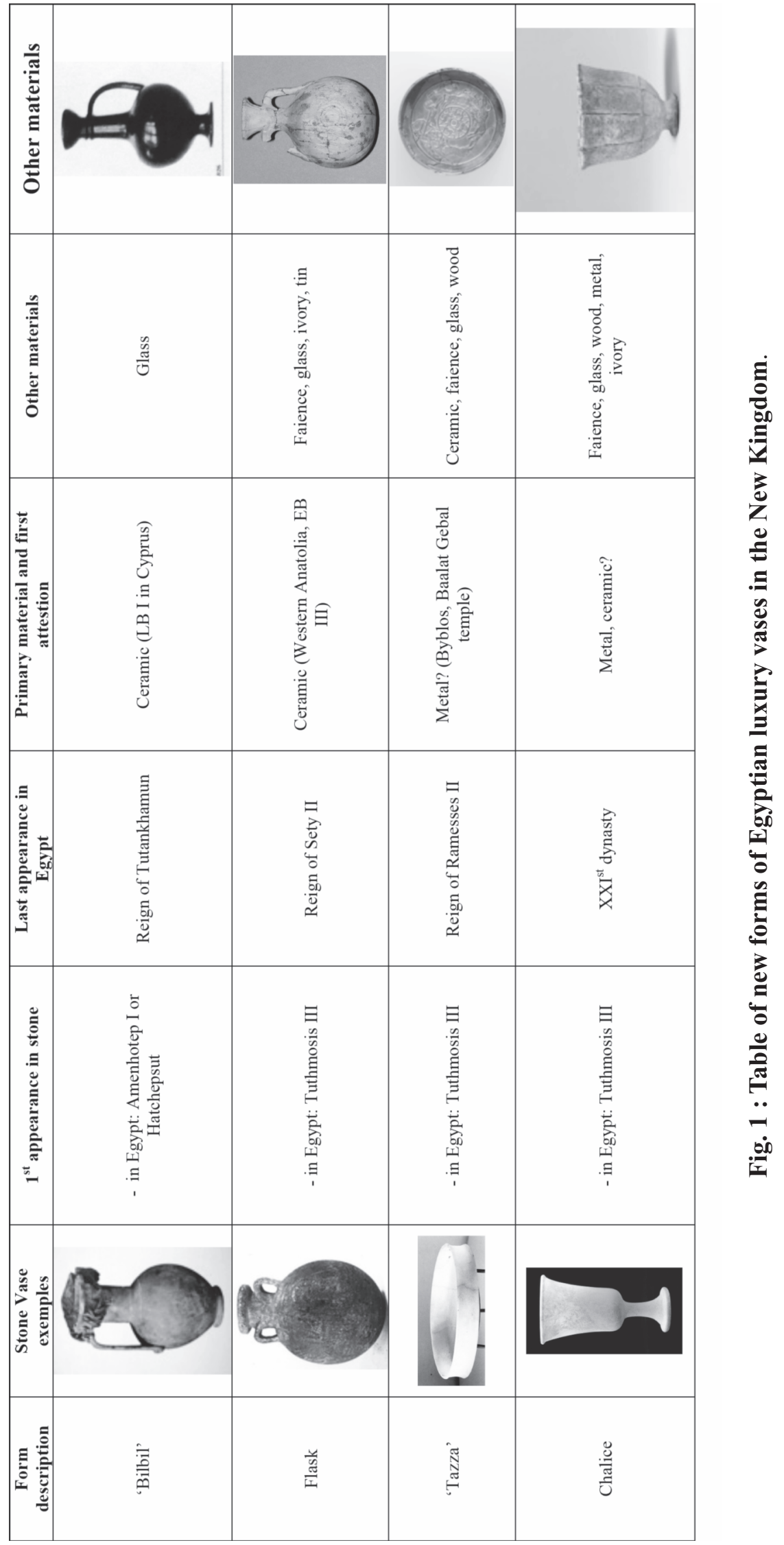




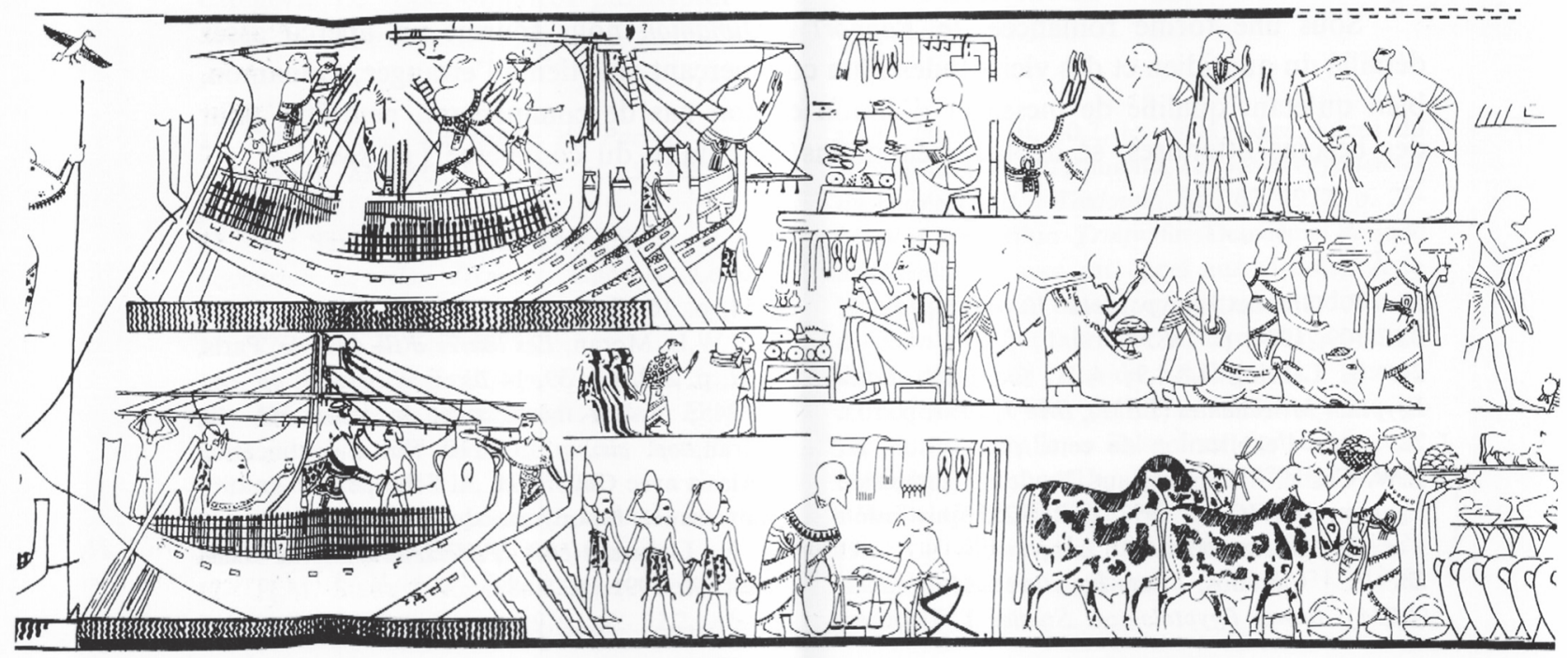

Fig. 2 : Canaanite merchants represented in the tomb of Kenamun TT162 (Grimal and Menu 1998: 162).

the king or the gods, or brought by merchants (Fig. 2) ${ }^{14}$. Some of them are of well-known origin. For example, the bilbil form derives from the Base Ring juglets of the LB I and II in Cyprus ${ }^{15}$, used, according to R. S. Merrillees, for opium trade and imported to Egypt from the Second Intermediate Period to the reign of Amenhotep IV-Akhenaton ${ }^{16}$. Other forms are more difficult to trace. Such is the case for the horizontal loop-handled amphora and the flask.

The ceramic amphora with horizontal loop handles first appears in Egypt in the tomb of Maiherperi $(\mathrm{KV} 36)^{17}$, but an earlier, Second Intermediate period example from Nubia is reported by R. Holthoer ${ }^{18}$. The first example in stone was found in Saqqara and bears the cartouche of Tuthmosis III ${ }^{19}$. The last ones come from Memphis and date to the $\mathrm{XX}^{\text {th }}$ dynasty ${ }^{20}$. The stone amphorae are usually big, but a miniaturized form was adapted for glass. This type is often called an amphoriskon ${ }^{21}$. We also find rare examples in faience ${ }^{22}$. The horizontal loop-handled amphora could be sealed with a lid, like the fake vessels found in the tomb of Amenhotep III's father in law, Yuya ${ }^{23}$. The type evolved during the Late Bronze, becoming less globular and with a broader neck and smaller handles ${ }^{24}$. The stone amphora is also well known in the Levant, south and north ${ }^{25}$. The glass type has rarely been found in the Near East, but two examples are known from the Aegean: in Rhodes and Kalyvia (Attica) ${ }^{26}$. There also is a Levantine stone type, called lugged-flask or lugged-pyxis, on which the handles are very small ${ }^{27}$.

The lentoid flask is a second common form of luxury vessel in the Late Bronze Age. The first attestations in stone in Egypt date from the reign of Tuthmosis III in Abydos and Gurob ${ }^{28}$. One of them is a variant called a Ring flask, comprising a tubular

14) PM I-II, IV-VI; Montet 1937; Vercoutter 1956; Wachsmann 1987.

15) Yon 1981: 35, 38.

16) Merrillees 1989.

17) Daressy 1902: pl. IV, n 24009, pl. V, nos 24021 and 24023.

18) Holthoer 1977: 102.

19) Bissing 1907: pl. IV, $\mathrm{n}^{\circ}$ 18734; Daressy 1897: ${ }^{\circ} 151.1$

20) Aston 1994: 152.

21) Nolte 1968

23) Petrie 1891: pl. XX, 2.

23) CG 51102 in Cairo Museum (PM I.2: 562-564).

24) Aston 1994: 152 (shape 176 b)

25) From Ain Shems (Sparks 2007: cat. 580); Ashod (Sparks 2007: cat. 571); Beth-Shan (Sparks 2007: cat. 572); Tell el-'Ajjul (Sparks 2007: cat. 570); Gezer (Macalister 1912: pl. CCXII); Kamid el-Loz (Sparks 2007: cat. 574); Lachish (Sparks 2007: cat. 575); Megiddo (Sparks 2007: cat. 576); Minet el-Beida (Caubet, 1991: 224, pl. III:13 and pl. III:14); Ras Shamra (Caubet 1991: 241, pl. IV.7).

26) Nolte 1968: pl. 8.16; Phillips 2008: $n^{\circ} 78$

27) Pella (James and McGovern 1993: fig. 111); Pella (Bourke and Sparks 1995: fig. 7); Tell Deir Alla (Franken 1992: 64).

28) Garstang 1901: pl. 18; Petrie 1891: pl. 27.4. 
body $^{29}$. Faience ${ }^{30}$, glass $^{31}$, or even ivory ${ }^{32}$ examples have also been discovered in Egypt. Furthermore, the flask is well known in the Levant and the Aegean in the entire range of materials ${ }^{33}$. During LB IIB, corresponding to the early Ramesside period in Egypt (ca. 1300-1100 B.C.), the body of the stone version became elongated, and no longer circular $^{34}$. Although the production of stone flasks seems to cease after the Late Bronze Age, the ceramic and faience industries maintained this form until the end of antiquity $^{35}$. Metallic examples are rare, undoubtedly due to the recyclable nature of metal. One tin example with a lid was discovered in a tomb of the XVIII ${ }^{\text {th }}$ dynasty in $\mathrm{Abydos}^{36}$. It is worth noting that the only other metallic flask attested so far was found in the Uluburun wreck ${ }^{37}$.

Whether the original material for these two vessel types was ceramic or metal is difficult to determine. However, because examples in clay are more numerous, the ceramic corpus can help to indicate the geographical origins of the form. A first direction in which to is towards the nearest neighbors in ancient Palestine and south Syria: the Canaanites, who seem to have introduced to Egypt many new practices and fashions during the Hyksos period ${ }^{38}$ and in the following centuries. A familiar instance of such borrowings is the Canaanite jar ${ }^{39}$.

The first attestations of horizontal loop (or bas$k e t^{40}$ ) handles on amphorae (also called kraters) in the Levant date from MB II ${ }^{41}$; but most of them be- long to the Late Bronze Age, in other words, the same period as their equivalents in other materials. As for the flask, small handles placed on either side of the neck are already visible on amphoriska produced in Canaan during EB I (ca. 3200-2900 B.C. $)^{42}$, and the tradition continued throughout the Early Bronze Age ${ }^{43}$. The body of these vessels is round or oval and the bottom is flat. Their production was abandoned during the Middle Bronze Age, when Palestine potters began to create more jugs and jars, such as the Canaanite jar already evoked. When the pilgrim flask appeared, at the end of MB or the beginning of LB I, it was already the type called pilgrim flask ${ }^{44}$, with a lentoid body not previously known in Canaan. Thus, Tomb 57 at Ugarit (MB III - LB I), contained a flask with a ring-shaped body ${ }^{45}$; whereas a flask in the later Tomb 75 (LB I) was lentoid with three handles: two placed symmetrically on the shoulder, and the third on the more concave side of the vase, between the neck and the body ${ }^{46}$. Consequently, flasks with two symmetrical handles from neck to shoulder became widely distributed from Ugarit to Tell el-Ajjul ${ }^{47}$.

These new ceramic types seem to have entered the northern Levant first ${ }^{48}$. It is thus logical to look farther north for the possible origin of these forms. According to R. Amiran, the origin of the flask is mysterious but that of the krater could be the Aegean ${ }^{49}$. P. Betancourt links them to the relations between the Levant and the Minoan world during the

29) Randall-MacIver and Mace 1899-1901: pl. 44.

30) Gurob (Petrie 1891: pl. 17.9 and 18.22); Sedment (Petrie and Brunton 1924: I, pl. 66.8); Saqqara (Bissing 1902 : CG 3673 ).

31) Gurob (Petrie 1891: pl. 17.35, 18.13, 18.15, 18.17, 20.11).

32) Fitzwilliam Museum Cambridge E 13.1901 (Randall-MacIver and Mace 1902: pl. 44).

33) In stone: Tell Atchana (Woolley 1955: pl. 82.22); Beth Shan (Sparks 2007: cat. 366); Tell Qasile (Mazar 1985: fig. 4.1); Tell Deir Alla (Sparks 2007: cat. 1089); Enkomi (Jacobsson 1994: ${ }^{\circ s} 58$, 59); Lachish (Sparks 2007: cat. 362, cat. 367); Minet el-Beida

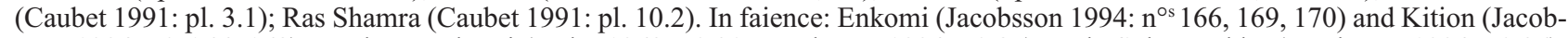
sson 1994: $\mathrm{n}^{\circ \mathrm{s}}$ 166, 168). In glass: Enkomi (Nolte 1968: ${ }^{\circ}$ 30; Jacobsson 1994: $\mathrm{n}^{\circ}$ 85); Hala Sultan Tekke (Jacobsson 1994: ${ }^{\circ}$ 86); Kalyvia (Phillips 2008: $\mathrm{n}^{\circ}$ 78).

34) Aston 1994: 157 (shape 195 b).

35) The Iron Age version is often called 'New Year's flask' because of the apotropaic formula inscribed in hieroglyphs on most of them (Blanquet 1992).

36) Ayrton 1904: pl. 17.20.

37) Yalçıı 2006: 609, n ${ }^{\circ} 132$.

38) To the Hyksos are attributed the introduction of horse chariotry, gods riding horses (Leclant 1960; Grandet 2008: 59-62), and the 'twenty squares' board game (Dunn-Vaturi and Bardiès-Fronty 2012: 52).

39) Leonard 1996; Cohen-Weinberger and Goren 2004.

40) Amiran 1959: 153.

41) Amiran 1959: p1. 29.3.

42) Farah North (Amiran 1959: pl. 9.19, 9.20), Jericho (Amiran 1959: pl. 11.13, 11.14, 13.9, 13.10).

43) EB II: (Amiran 1959: pl. 15.14, 15.14); EB IV (Amiran 1959: pl. 22.12, 22.13, 22.14, 23.11, 24.10, 24.18, 24.19).

44) Amiran 1959: 166.

45) Schaeffer 1949: pl. LX = Schaeffer 1978: fig. 4.1.

46) Schaeffer 1978: fig. 5.15.

47) Ugarit: Schaeffer 1978: fig. 23.3; Tell el-Ajjul: Amiran 1959 : pl. 51.5.

48) Lilyquist 1996: pl. 5.3; Aruz 2009: 59

49) Amiran 1959: 134 


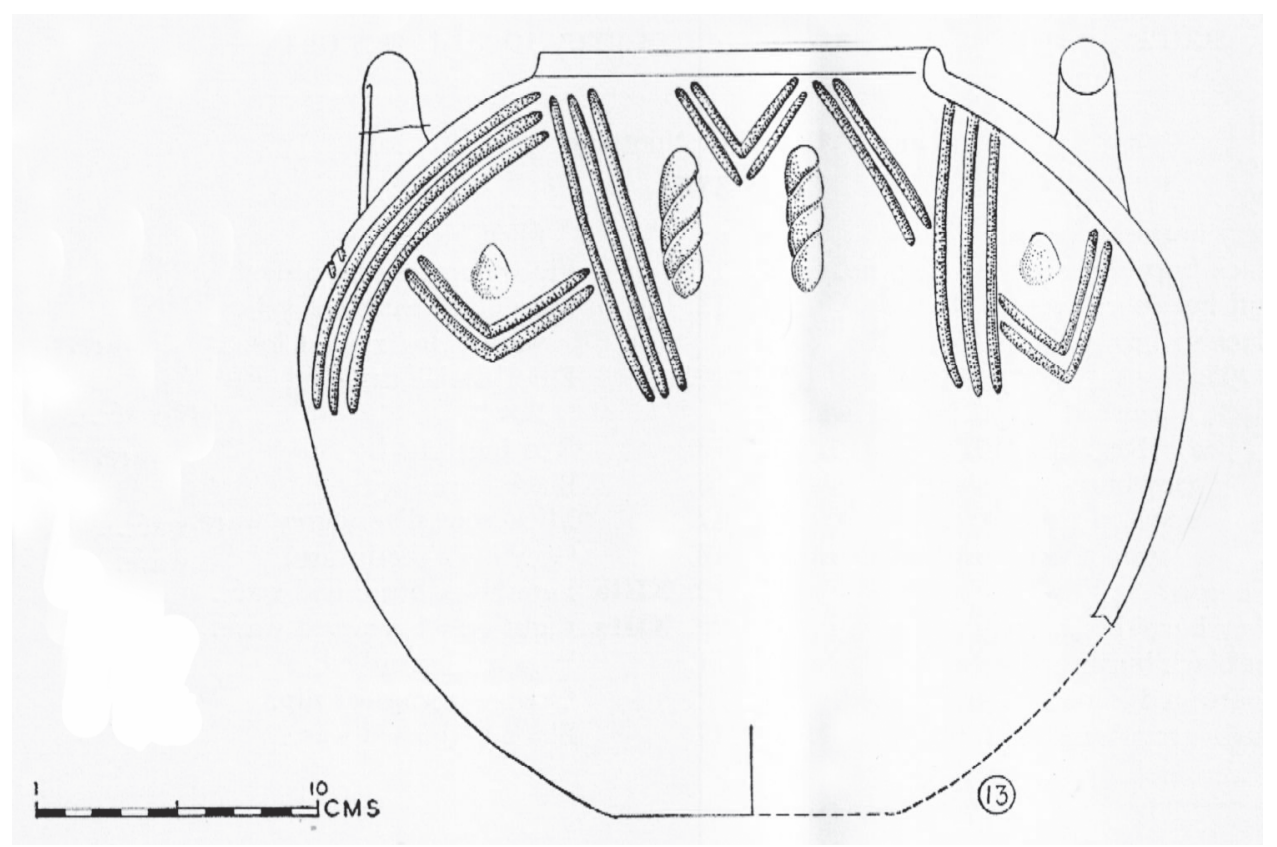

Fig. 3 : Amphora with horizontal loop handles from Beycesultan (Lloyd and Mellaart 1962: pl. XIII).

Middle Bronze Age ${ }^{50}$. M. Guichard's study of the Mari tablet corpus dealing with the furnishing of tablewares for the palace shows that most of the luxury vessels derived from international trade and exchange ${ }^{51}$. Minoan vases were imported but also imitated, and the main source of supply was in the northwest: from Aleppo to the south of Anatolia. Aleppo and Karkemish were the big centers at this time ${ }^{52}$, when they oversaw the trade system between Anatolia, Mesopotamia and the Aegean. To their north, Anatolia is a region or rather a congregation of regions where ceramic traditions were varied and rich, and where horizontal loop handles are known from the end of the Late Neolithic - through the Early Bronze Age ${ }^{53}$, together with the flask (Fig. 3) ${ }^{54}$. In the Aegean world, the horizontal loop handles were adopted with other new shapes and features of
Anatolian origin during EM I (3200-2600 B.C. $)^{55}$. The horizontal loop handles became a common feature during the Middle Bronze Age in Anatolia as well as in the Aegean ${ }^{56}$, where the ceramic form was imitated in stone ${ }^{57}$. It was also among the forms applied to Kamares Ware amphorae, which were imported to the Levant and Egypt ${ }^{58}$. The use of these imports indicates, as R. S. Merrillees states, middle class rather than royal connections ${ }^{59}$. However, some of these forms were copied in more luxurious materials, such as the silver vases found in the tombs I and II (ca. 1830-1770 B.C.) of the royal necropolis of Byblos ${ }^{60}$, and the faience vessel found in 'Knossos treasury', compared by A. Evans to the Gyblite vases even if from a more recent context (Fig. 4) ${ }^{61}$. The silver vessels from Byblos were contemporary with the archives from the royal palace of Mari, and can be

50) Communication from P. Betancourt to Lilyquist (Lilyquist 1995: 9).

51) Guichard 2005

52) Guichard 2005: 1967-169.

53) Alacahöyük: Chalcolithic (Koşay and Akok 1966: pl. 148) and EB I (Koşay 1938: pl. LXIX, LXXVII); Beycesultan EB II (Lloyd and Mellaart 1962: pl. IX, XIII, XVI).

54) The EB I flasks discovered in Beycesultan are globular (Lloyd and Mellaart 1962: pl. XVIII), but they become lentoid in the MB Karum period (Schoop 2011: 253).

55) Betancourt 2008 : 70-71, fig. 5.32

56) MacGillivray 1998: 80, 106.

57) Cf. two jars in chloritite from Knossos and Mycenae (Bevan 2007: 117, fig. 6.13).

58) Merrillees 2003.

59) Merrillees 2003: 139.

60) Montet 1969: pl. CXI, CXII.

61) Evans 1928: 825, fig. 541 


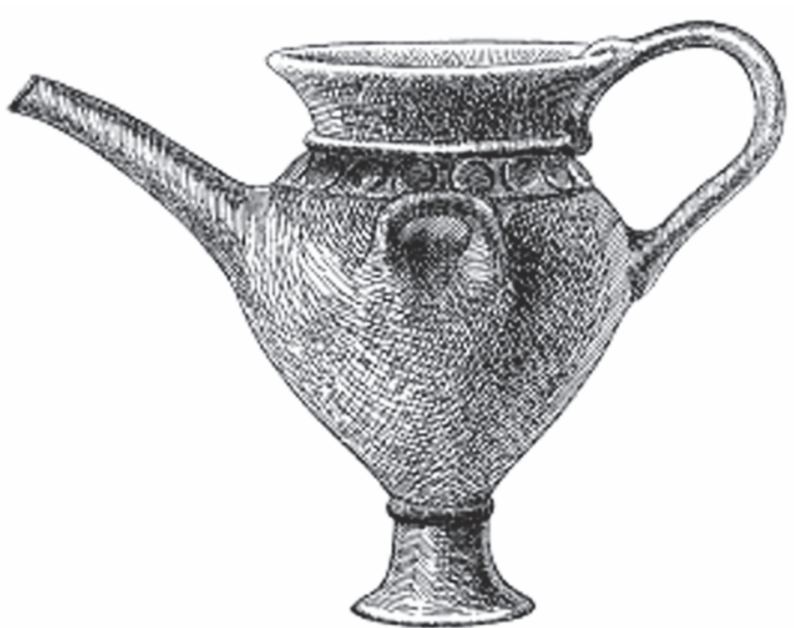

Fig. 4 : Faience vase from the Knossos 'treasury' (Evans 1928: fig. 541b).

considered an illustration of 'Minoan type' metal vases used in a royal context.

As for the lentoid flask, the form is undoubtedly of Anatolian origin: it is found in Western Anatolian sites like Troy starting with EB II (2600-2250 B.C.), and shortly thereafter in Central Anatolia at Acemhöyük and Kültepe ${ }^{62}$. The lentoid flask was eventually adopted and developed in the Karum Period, and maintained during the Hittite Period (Fig. 5) ${ }^{63}$. Whereas the little symmetrical handles of the so-called pilgrim flask were popular throughout the Eastern Mediterranean, the vertical handle and the ring-body seem to be northern features found mostly in Anatolia and the North Levant. The ringflasks, even more ancient ${ }^{64}$, were rarely adapted to materials other than pottery.

It appears that this generation of new luxury vessel forms was related to international trade. This intensified in the Near East during the Middle Bronze Age, at the instigation of Assyrian merchants during the Karum period (ca. 1950-1770 B.C.), and laterin the hands of north Syrian kingdoms such as Ugarit and Aleppo. The new forms that flourished during this period were the ones adopted by the Egyptian kings of the New Kingdom and their courtiers, including the three Asiatic wives of Tuthmosis III ${ }^{65}$ and the general Djehuty, 'overseer of the northern countries' for the same king ${ }^{66}$.

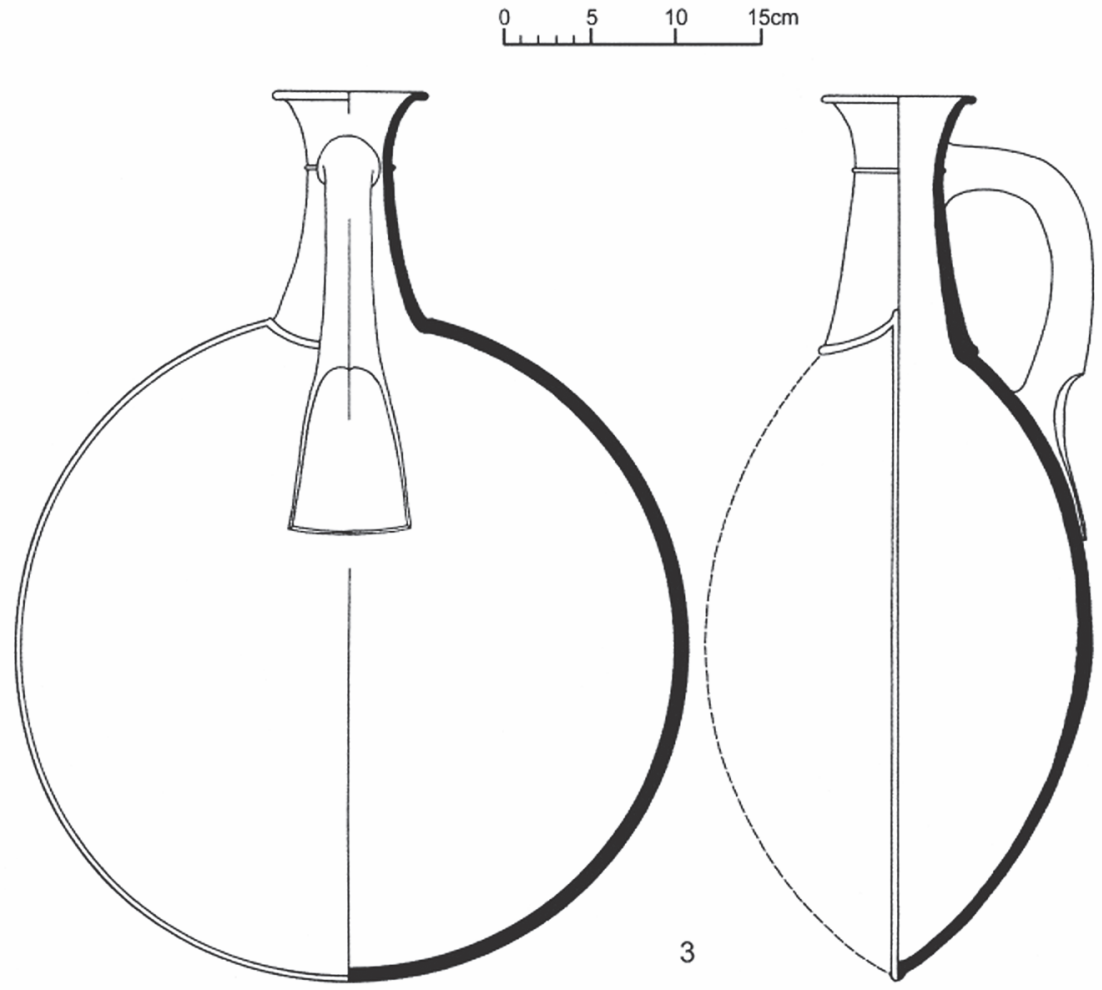

Fig. 5 : Lentoid flask from Hattusha (Schoop 2011: fig. 5).

62) Mellink 1989.

63) Schoop 2011: 252-253.

64) Kulakoğlu 1998.

65) Lilyquist 2003.

66) Lilyquist 1998. 
Why is it so important to trace back the first appearances of these features and forms? They don't say much about the techniques in use, or the artisans and workshops. The issue instead applies to 'style" ${ }^{67}$, or even 'fashion'. The fact that very ancient Anatolian shapes were imitated and transformed in North Syria, the Levant, the Aegean and Egypt, to become one of the most characteristic forms of Egyptian lux- ury vases, provides significant evidence of a different sort: it reflects the scope of artistic influences, and to some extent, counterbalances the archaeological data for Near Eastern luxury items, whose paucity blurs our perception of artistic exchange and influences.

H.B.

\section{BIBLIOGRAPHY}

Aldred, C. et al., 1979 ( $1^{\text {st }}$ ed.): L'Empire des conquérants : L'Egypte au Nouvel Empire, Gallimard, Paris.

Amiran, R., 1959: Ancient pottery of the Holy Land: From its beginning in the Neolithic Period to the end of the Iron Age, Massada Press, Jerusalem.

Aston, B. G., 1994: Ancient Egyptian Stone Vessels. Material and Forms, SÄGA 5, Heidelberg.

Aruz, J. et al., 2009: Beyond Babylone art, trade, and diplomacy in the Second Millennium B.C., Metropolitan Museum of Art, New York.

- (eds.) 2013: Cultures in contact: from Mesopotamia to the Mediterranean in the second millennium B.C., Metropolitan Museum of Art, New York.

Ayrton E. R. et al., 1904: Abydos III, The Egypt Exploration Fund, London.

Blanquet, Cl.-H., 1992: "Typologie de la bouteille de Nouvel An", in Obsomer, Cl. and Oosthoek, A.-L. (eds.), Amosiadès: mélanges offerts au Professeur Claude Vandersleyen par ses anciens étudiants, Université catholique, Louvain-la-Neuve: 49-54.

Betancourt, P. P., 1985: The History of Minoan Pottery, University Press, Princeton.

- 1998: "Middle Minoan Object in the Near East", in Cline, E. H. and Harris-Cline, D. (eds.), The Aegean and the Orient in the second millenium: proceedings of the 50th anniversary symposium, Cincinnati, 18-20 April 1997, AEGAEUM 18, Liège: 18-20.

-2008: The Bronze Age begins: the ceramics revolution of early Minoan I and the new forms of wealth that transformed prehistoric society, INSTAP Academic Press, Philadelphia.

Bevan, A., 2007: Stone Vessels and Values in the Bronze Age Mediterranean, University Press, Cambridge.

Bissing, W., 1902: $C G C n^{\circ}$ 3618-4000, 1800118037, 18600, 18603, Fayengefässe, Holzhausen, Vienna.

- 1907: CGC $n^{\text {os }}$ 18065-08793, Steingefässe, Holzhausen, Vienna.

Bourke, S.-J. and Sparks, R.-T., 1995, "The DAJ Excavations at Pella in Jordan 1963/64", in Bourke, S. and
Descoeudres, J.-P. (eds.), Trade, Contact and the Movement of Peoples in the Eastern Mediterranean. Studies in Honour of J. Basil Hennessy, Mediterranean Archaeology Supplement 3, Sydney: 149-167.

Caubet, A., 1991 : "Repertoire de la vaisselle de pierre. Ougarit 1929-1988", in Yon, M. (ed.), Ras Shamra-Ougarit VI, Arts et industries de la Pierre, Paris: 204-264.

Cohen-Weinberger, A. and Goren, Y., 2004: "'Levantine-Egyptian Interactions during the $12^{\text {th }}$ to the $15^{\text {th }}$ Dynasties based on the Petrography of the Canaanite Pottery from Tell el-Dabca", Ägypten und Levante 14: 69-100.

Daressy, G., 1897: "Deux vases gradués du Musée de Ghizeh", Bulletin de l'Institut d'Égyptien, sér. 3, n 8, Cairo: 149-152.

- 1902: Fouilles de la Vallée des Rois (1898 - 1899), $C G C n^{\circ s}$ 24001-24990, Le Caire.

De Vos, J., 2008: 'Les denrées en sémitique occidental et autres langues des les sources nilothiques. Les Levantins et Ioniens en Egypte, des portes du Delta à la fenêtre d'apparition", Res Antiquae 5, Louvain: 67-93.

Dunn-Vaturi, A.-E. and Bardiès-Fronty, I., 2012: Art du Jeu. Jeu dans l'art. De Babylone à l'Occident médiéval, Editions de la RMN, Musée de Cluny, Paris.

El Khouli, A., 1978: Egyptian stone vessels predynastic period to dynasty III: typology and analysis, Deutsches Archäologisches Institut Abteilung, Mainz.

Evans A., 1921-1396: The Palace of Minos: a comparative account of the successive stages of the early cretan civilization as illustrated by the discoveries at Knossos. Vol. II. 2, Macmillan, London.

Feldman, M. H., 2005: Diplomacy by design: luxury arts and an "international style" in the ancient Near East, 1400-1200 B.C., University Press, Chicago.

Franken, H. J., 1992: Excavations at Tell Deir'Alla: the Late Bronze Age sanctuary, Brill, Louvain.

Freed, R. E. (ed.), 1982 : Egypt's Golden Age: The art of the Living in the New Kingdom, 1558-1085 B.C., Museum of Fine Arts, Boston. 
Furumark, A., 1941, The Mycenaean pottery: Analysis and classification, Svenska institutet i Athen, Stockholm.

Garstang, J., 1901: El Arábah: a cemetery of the Middle Kingdom; survey of the Old Kingdom temenos; graffiti from the temple of Sety, Quaritch, London.

Grandet, P., 2008: Les Pharaons du Nouvel Empire: une pensée stratégique, Editions du Rocher, Monaco.

Grimal, N. and Menu, B., 1998 : Le Commerce en Egypte ancienne. Actes du colloque organisé au Caire en octobre 1996 par l'AIDEA et l'IFAO, Bibliothèque d'étude 121, IFAO, Le Caire.

Guichard, M., 2005: La Vaisselle de luxe des rois de Mari, Matériaux pour le dictionnaire de Babylonien de Paris. T. 2, Archives royale de Mari XXXI, ERC, Paris.

Harrell, J. A., 2012 : s.v. "Gemstones", in Wendrich, W. (ed.), UCLA Encyclopedia of Egyptology, Los Angeles.

Holthoer, R., 1977: New Kingdom Pharaonic Sites. The Pottery, SJESA 51, Lund.

Jacobsson, I., 1994 : Aegyptiaca from the Late Bronze Cyprus, Studies in Mediterranean Archeology CXII, Jonsered.

James, F. W. and Mcgovern, P. E., 1993: The Late Bronze II Egyptian Garrison at Beth Shan: A Study of Levels VII and VIII, Philadelphia.

Kammerer-Grothaus, H., 1998: "Keramik aus den Mastabas des Alten Reiches", in Bolesław, G. et al., Frühe Keramik und Kleinfunde aus El-Târif, Zabern, Mainz: 5999.

Koșay, H. Z., 1938: Türk Tarih Kurumu Tarafindan Yapılan Alaca Höyük Hafriyatı. 1936'daki Çalışmalara ve Keşiflere ait Rapor, Türk Tarih Kurumu Yayınları V. seri 2, Ankara.

Kosay, H. Z. and Akok, M., 1966 : Türk Tarih Kurumu Tarafindan Yapılan Alaca Höyük Kazısı. 194048'deki Çalı̧̧malara ve Keşiflere ait Rapor, Türk Tarih Kurumu Yayınları V. seri 2, Ankara.

Kulakoğlu, F., 1998 : "'Ring-Shaped Vases Discovered at Kültepe", in Mikasa, T., Essays on Ancient Anatolia in the Second Millenium B.C., Harrassowitz, Wiesbaden.

Leclant, J., 1960: “Astarté à cheval d'après les représentations égyptiennes", Syria 37: 1-67.

Leonard, A. Jr, 1996: "'Canaanite jars' and the Late Bronze Age Aego-Levantine Wine Trade", in McGovern, P.E. et al. (eds.), The Origins and Ancient History of Wine, Food and Nutrition in History and Anthropology 11, Amsterdam: 233-254.

Lilyquist, Chr., 1995: Egyptian Stone Vessels, Khian through Tuthmosis IV, The Metropolitan Museum of Art, New York.

- 1996: "Stone vessels at Kâmid el-Lôz, Lebanon: Egyptian, Egyptianizing, or non-egyptian?", Kâmid elLôz 16: 133-173.

- 1997: "A foreign vase representation from a new Theban tomb (The Chapel for MMA 5A P2) ", in Phillips, J. (ed.), Ancient Egypt, the Aegean and the Near East.
Studies in honour of Martha Rhoads Bell, San Antonio: 307-343.

- 1998 : "The gold bowl naming general Djehuty: A study of objects and early Egyptology", Metropolitan Museum of Art Journal 23: 5-68.

- 2003: The Tomb of The Three Foreign Wives of Tuthmosis III, Metropolitan Museum, New York.

- 2009: "Mayana K 1300 at Sedment el-Gebel: traces of ethnicity", in Magee, D., Bourriau, J. and Quirke, S. (eds.), Sitting beside Lepsius: Studies in honour of Jaromir Malek at the Griffith institute, Louvain: 289-315.

- 2012: "Treasures from Tell Basta: Godesses, Officials, and Artists in an International Age", Metropolitan Museum Journal 47: 9-72.

Lloyd, S. and Mellart, J., 1962: Beycesultan I, The British Insitute of Archaeology at Ankara, Occasional Publications $\mathrm{N}^{\circ} 8$, London.

Lloyd, S. and Murray, A., 1995: Beycesultan III.2: Late Bronze Age and Phrygian Pottery and Middle and Late Bronze Age Small Objects, London.

Macalister, R. A. S., 1912: Excavations at Gezer II, Published for the Committee of the Palestine Exploration Fund, London.

MacGillivray, J. A., 1998: Knossos: Pottery groups of the Old Palace period, British School of Athens, London.

Mazar A., 1985: Excavations at Tell Qasile. Part 2, Various Finds, The Pottery, Conclusions, Appendices, Qedem 20, Institute of Archaeology, Jerusalem.

Mellink, M. J., 1989 : “Anatolian and Foreign Relations of Tarsus in the Early Bronze Age", in Mellink, M. J., et al. (eds.), Anatolia and the Near East: Studies in Honour of Tahsin Özgüç, Türk Tarih Kurumu Yayınları, Ankara: 319-331.

Merrillees, R. S., 1989: "Highs and lows in Holy Land: Opium in Biblical times", Eretz-Israel 20: 148-154.

- 2003: "The First Appearances of Kamares Ware in the Levant", Ägypten und Levante / Egypt and the Levant XIII: $127-142$.

Midant-Reynes, B., 2003 : Aux origines de l'Egypte : du Néolithique à l'émergence de l'Etat, Fayard, Paris.

Montet, P., 1937: Les Reliques de l'art syrien dans l'Egypte du Nouvel Empire, Publications de la Faculté de Lettres de 1'Université des Strasbourg 76, Paris.

- 1969: Byblos et l'Egypte : quatre campagnes de fouilles à Gebeil, 1921-1922-1923-1924, Bibliothèque archéologique et historique 11, Paris.

Nolte, B., 1968, Die Glasgefässe im alten Ägypten, MÄS 14, Berlin.

Özgüc, T., 1986: Kültepe - Kanis II. New researches at the Trading Center of the Ancient Near East, Türk Tarih Kurumu Yayınları, V. Seri Sayı 41, Ankara.

Petrie, W. M. F. et al., 1891: Illahun, Kahun and Gurob, Nutt, London.

- 1937: The Funeral Furnitures of Egypt. Stone and Metal Vases, BSAE 43, London.

Petrie, W. M. F. and Brunton, G., 1924: Sedment I, II, BSAE 34-35, London. 
Phillips, J., 2008 : Aegyptiaca on the island of Crete in their chronological context: A critical review, Contributions to the chronology of the Eastern Mediterranean 18; Österreichische Akademie der Wissenschaften, Denkschriften der Gesamtakademie 49, Vienna.

Pierrat-Bonnefois, G., 2014 : "Les échanges entre l'Egypte et le Proche-Orient", in Andreu-Lanoë, G. and Morfoisse, F., Sesostris. Pharaon de légende, Snoek, Gand : 170-181.

PM: Porter, B. and Moss, R., 1931-2012: Topographical Bibliography of Ancient Egyptian Hieroglyphic Texts, Reliefs and Paintings, I-VIII, Oxford.

Randall-Maciver, D. and Mace, A. C., 1899-1901: El Amrah and Abydos, Egypt Exploration Fund, London.

Redford, D. B., 1993 : Egypt, Canaan and Israel in the Ancient Times, University Press, Princeton.

Reisner, G. A., 1931: Mycerinus. The Temples of the Third Pyramid at Giza, Harvard University Press, Cambridge (Massachusetts).

Schaeffer, C. F.-A., 1949: Ugaritica II, Etudes relatives aux découvertes de Ras Shamra, Geuthner, Paris.

- 1978: Ugaritica VII, Etudes relatives aux découvertes de Ras Shamra, Geuthner, Paris.

Schoop, U.-D., 2011: "Hittite pottery: A summary", in H. Genz and Mielke D. P. (eds.), Insights into Hittite History and Archaeology, Louvain: 241-273.
Shaw, I., 2000 : The Oxford History of Ancient Egypt, University Press, Oxford.

Sparks, R., 2007: Stone Vessels in the Levant, Palestine Exploration Found Annual VIII, Leeds.

Vandier, J., 1952: Manuel d'archéologie égyptienne I. Les Epoques de formation, Paris.

Vercoutter, J., 1956: L'Egypte et le monde égéen préhellénique. Etude critique des sources égyptiennes (Du début de la XVIII è la fin de la XIX ${ }^{e}$ Dynastie), BdE 22, Le Caire.

Warburton, D., 2001 : Egypt and the Near East: Politics in the Bronze Age, Recherches et publications, Neuchâtel.

Woolley C. L., 1955: Alalakh: An account of the excavations at Tell Atchana in the Hatay, 1937-1949, RRCSAL 18, Oxford.

Yalçın, U. et al. (eds.), 2006: Uluburun Gemisi. 3000 Yıl Önce Dünya Ticareti, DBM Yayınları, Istanbul.

Yon, M., 1981: Dictionnaire illustré multilingue de la céramique du Proche Orient ancien, COM 10, Arch. 6, Lyon. 


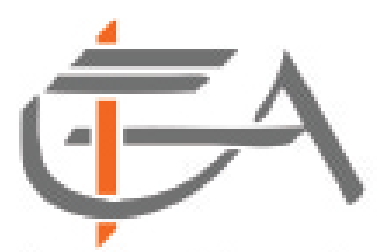

Institut Français d'Etudes Anatoliennes

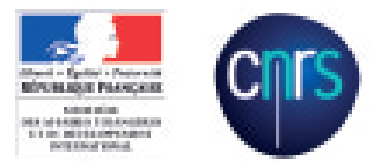

Eglise paléochrétienne de Bindéos (Pisidie), détail de la mosaïque ornant le sal de la nef centrale, $4^{e} \mathrm{~s}$. ap. J.-C. 